\title{
Pola Perjalanan Wisata di Kabupaten Nias Barat, Sumatera Utara
}

\author{
Liyushiana \\ Politeknik Pariwisata Medan \\ E-mail : liyushiana@poltekparmedan.ac.id
}

\begin{abstract}
The regency of Nias Barat (West Nias) has many potential tourist destinations, unfortunately not many travel package specifically offer the visit to explore the tourism objectsin this region. That is the reason this study aims to design effective and efficient travel patterns in West Nias Regency using a destination region loop approach. The focus of this study is to identify how the state of tourism in West Nias Regency, the travel routes in West Nias Regency and especially how to develop travel patterns that most suitable to West Nias. The method employs descriptive analysis technique with data collected from observation, documentation, interviews and literature study. The research results the identification of several selected tourist objects that can be visited in this district, such as Sirombu Beach, Asu Island, Gu'u Beach, Fari'i Beach, Ture Beach, Fadaya Beach, Valaete Beach, Bawa Island, Bale, Bukit Hermon, Houses adat, Batu Megalit in Lahomi Village, Lolozirugi Village and Sisarahili Village.
\end{abstract}

\section{Keywords: Travel Patterns, Travel Routes, Travel Destinations}

Abstrak - Pariwisata di Kabupaten Nias Barat sangat potensial, sayangnya belum banyak produk wisata yang khusus menawarkan objek-objek wisata di kabupaten ini. Oleh sebab itu, penelitian ini bertujuan untuk merancang pola perjalanan wisata yang efektif dan efisien di Kabupaten Nias Barat dengan pendekatan destination region loop. Fokus penelitian ini untuk mengidentifikasi bagaimana keadaan pariwisata di kabupaten Nias Barat, bagaimana rute perjalanan wisata di Kabupaten Nias Barat dan terutama bagaimana pengembangan pola perjalanan wisata (travel pattern) yang coba diformulasikan oleh penulis dalam penelitian ini. Metode yang digunakan penulis adalah metode deskriptif analisis dengan teknik pengumpulan data dengan cara observasi, dokumentasi, wawancara dan studi kepustakaan. Dari hasil penelitian diketahui bahwa beberapa objek wisata pilihan yang dapat dikunjungi di kabupaten ini adalah Pantai Sirombu, Pulau Asu, Pantai Gu'u, Pantai Fari'i, Pantai Ture, Pantai Fadaya, Pantai Valaete, Pulau Bawa, Bale, Bukit Hermon, Rumah adat, Batu Megalit di Desa Lahomi, Desa Lolozirugi dan Desa Sisarahili.

Kata Kunci : Pola Perjalanan Wisata, Rute Perjalanan, Destinasi Wisata

\subsection{Latar Belakang}

Provinsi Sumatera Utara di Indonesia merupakan provinsi yang memiliki aset pariwisata yang begitu banyak, yang terdiri dari berbagai jenis wisata yakni wisata bahari, wisata etnik, wisata budaya, wisata sejarah, wisata alam, wisata agro, wisata kota, wisata sosial, wisata alternatif dan sebagainya yang tersebar di berbagai daerah. Salah satu tempat yang memiliki potensi wisata yang besar adalah kabupaten Nias Barat. Kabupaten Nias Barat adalah salah satu kabupaten di Provinsi Sumatera Utara, Indonesia. Kabupaten ini diresmikan oleh Menteri Dalam Negeri Indonesia, Mardiyanto, pada 26 Mei 2009, sebagai salah satu hasil pemekaran dari Kabupaten Nias.

Sama seperti daerah lainnya di Sumatera Utara, Kabupaten Nias Barat memiliki banyak destinasi wisata yang berpotensi cukup besar untuk menarik minat wisawatan. Di Kabupaten Nias Barat terdapat sejumlah objek wisata dimulai dari wisata bahari yang eksotis, bentang alam dan juga ciri khas budaya. Dalam buku profil pariwisata kabupaten Nias Barat yang disusun oleh Dinas Pariwisata dan Kebudayaan Kabupaten Nias Barat saat ini sedang mengembangkan beberapa objek wisata diantaranya adalah Pantai Sirombu, Pulau Asu, Pantai Gu'u, Pantai Fari'i, Pantai Ture, Pantai Fadaya, Pantai Valaete, Pulau Bawa, Bale, Bukit Hermon, Rumah Adat, Batu Megalit di Desa Lahomi, Desa Lolozirugi dan Desa Sisarahili. Diharapkan pengembangan beberapa objek wisata ini menjadi destinasi utama dan menjadikannya sebagai tujuan wisata yang dapat mendongkrak pertumbuhan ekonomi Kabupaten Nias Barat. Namun, seiring berkembangnnya pariwisata di Kabupaten Nias Barat, saat ini pariwisata masih belum memberikan dampak yang optimal terhadap kunjungan ke objek wisata yang tersebar di Kabupaten Nias Barat. Hal ini dibuktikan dengan rendahnya jumlah kunjungan wisatawan menuju objek wisata di Kabupaten Nias Barat.

Berdasarkan analisis data jumlah wisatawan baik wisatawan domestik maupun wisatawan mancanegara yang datang 
berkunjung di Kabupaten Nias Barat selama 7 tahun, dari tahun 2010 - tahun 2017 hanya sebanyak 4.396 orang. Artinya rata-rata hanya ada 600an jumlah wisatawan mancanegara yang datang per-tahunnya.

Dibanding destinasi wisata lain di Sumatera Utara, jumlah kunjungan wisatawan mancanegara ini dipastikan cukup rendah. Indikasi yang ada kemungkinan karena banyak potensi pariwisata Kabupaten Nias Barat yang belum terpublikasikan sehingga tidak banyak wisatawan yang mengetahuinya, padahal destinasi wisata tersebut sangat menarik untuk dikunjungi. Selain itu pola perjalanan wisata (travel pattern) juga belum disajikan dengan tepat. Pola perjalanan wisata (travel pattern) yang komprehensif dengan mengemas informasi terpadu terhadap rekomendasi destinasi wisata dan alur perjalanan dapat membantu wisatawan dalam mendapatkan informasi dan mendukung biro perjalanan wisata (BPW) dalam pembuatan paket wisata di Kabupaten Nias Barat.

Gambaran diatas yang menggugah keingintahuan penulis sehingga mengangkat studi penelitian dengan judul "Kajian Pola Perjalanan Wisata di Kabupaten Nias Barat, Sumatera Utara". Adapun tujuan penelitian ini adalah untuk menjawab pertanyaan penelitian sebagai berikut:

1. Bagaimana keadaan pariwisata di Kabupaten Nias Barat?

2. Bagaimana rute perjalanan wisata di Kabupaten Nias Barat?

3. Bagaimana pengembangan pola perjalanan wisata (travel pattern) di kabupaten Nias Barat?

Penelitian ini diharapkan dapat member manfaat sebagai berikut:

1. Sebagai kontribusi ilmu bagi pengembangan pariwisata daerah, terutama di Kabupaten Nias Barat

2. Menjadi referensi bagi pengunjung yang akan dating ke Kabupaten Nias Barat

3. Menjadi sumber rujukan bagi travel agent dalam menyusun paket wisata di kabupaten Nias Barat

4. Menjadi sumber informasi bagi pemerintah (misalnya Dinas Pariwisata Daerah) dalam menawarkan Kabupaten Nias Barat sebagai destinasi kunjungan wisata.

\subsection{Kajian Pustaka}

\subsubsection{Pola Perjalanan Wisata}

Dalam kamus besar bahasa Indonesia kata pola berarti model, sedangkan kata perjalanan yang berasal dari kata dasar jalan dalam kamus besar bahasa Indonesia berarti perlintasan dari suatu tempat ke tempat lain dan arti perjalanan sendiri dalam kamus besar bahasa Indonesia tersebut adalah kegiatan perpindahan barang atau orang dari suatu tempat ke tempat lain melalui suatu perlintasan.

Dalam materi seminar tentang pola perjalanan Indonesia tanggal 29 September 2014 oleh Basoeki dijelaskan bahwa pola perjalanan pariwisata adalah struktur, kerangka dan alur perjalanan wisata dari satu titik destinasi ke titik destinasi lainnya yang saling terkait yang berisi informasi tentang fasilitas, aktifitas dan pelayanan yang memberikan berbagai pilihan perjalanan wisata bagi industri maupun individu wisatawan untuk mempengaruhi pengambilan keputusan dalam melakukan perjalanan wisata (qtd. in Fajri, Khoirul, Indrianty, Septy \& Edison, Emron; 2018:3)

Dalam materi ASITA (Association Of the Indonesia Tour \& Travel) 23 mei 2011, pola perjalanan adalah data tentang segala sesuatu berkait dengan dimana, mengapa, kapan dan bagaimana orang melakukan perjalanan wisata dengan tujuan agar para wisatawan dapat merancang perjalanan yang efektif dan efisien sesuai kebutuhannya (Ismedi, 2011)

Menurut Basoeki dalam materi seminar pola perjalanan Indonesia, secara umum Pola Perjalanan Wisata dapat dibagi menjadi 6 (enam) kategori yaitu:

1. Single Point yaitu wisatawan melakukan kunjungan disuatu destinasi atau daya tarik wisata dan kembali dengan rute yang sama, adapun pola ini diberi nama Direct Route atau Single Destination.

2. Base Site yaitu wisatawan menuju satu destinasi utama sebagai base camp selanjutnya berkunjung ke destinasi atau daya tarik wisata lain yang menjadi sekunder, pola ini diberi nama Base camp Day Trip.

3. Stop Over yaitu wisatawan berkunjung ke suatu destinasi utama, dimana selama perjalanan terdapat daya tarik wisata yang dikunjungi selama menuju atau kembali ke destinasi utamanya, pola ini diberi nama En Route Stop Over.

4. Chaining Loop yaitu wisatawan mengunjungi beberapa destinasi atau daya tarik wisata tanpa mengulangi. Berhenti di destinasi atau daya tarik wisata diantara jalur melingkar yang belum tentu terkait. Wisatawan berkunjung ke daya tarik wisata terkait dengan destinasi yang sedang dikunjungi. Pola ini diberi nama Full Orbit Round Trip.

5. Destination Region Loop yaitu kombinasi antara single point dan chaining loop yang dikenal dengan nama Regional Tour Destination Area Loop. 
6. Complex neighbourhood yaitu gabungan beberapa atau keseluruhan pola- pola perjalanan, wisatawan pergi dari suatu destinasi ke destinasi lain tanpa mengulangi. Pola ini menggambarkan kompleksitas pola pergerakan wisatawan yang memungkinkan variasi dan campuran pola perjalanan yang berbeda. Pola ini lebih dikenal dengan nama Multiple Destination area loop.

Menurut Hadiwijoyo (2012 : 50) tujuan utama pengembangan pola perjalanan wisata tidak terlepas dari tujuan utama pembangunan pariwisata yang bertujuan untuk :

1. Persatuan dan kesatuan bangsa

2. Penghapusan kemiskinan (poverty alleviation)

3. Pembangunan berkesinambungan

4. Pemenuhan kebutuhan hidup dan hak asasi manusia

5. Pendekatan ekonomi dan insdustri

6. Pengembangan teknologi

Berikutnya menurut Richard (2000:90)

faktor yang mempengaruhi perjalanan wisata yang selanjutnya akan menjadi panduan pengembangan pola perjalanan wisata antara lain :

1. Daerah tujuan yang akan dituju

2. Jenis transportasi yang hendak digunakan

3. Jenis akomodasi yang akan ditempati

4. Rute yang akan ditempuh

5. Aktivitas yang akan dilakukan ditempat tujuan

6. Pengaturan perjalanan apakah secara individu atau kelompok

7. Besarnya biaya yang harus disiapkan

8. Pemilihan agen perjalanan

9. Kapan mulai (start) atau berangkat dan hingga kapan

\subsubsection{Variabel dan Parameter}

Pengembangan Pola Perjalanan

Basoeki (2014: 33) membagi variabel yang perlu dipertimbangkan dalam pengembangan pola perjalanan wisata dalam dua komponen: karakteristik destinasi dan karakteristik wisatawan. Berikut disajikan variable dan parameter untuk setiap variabel tersebut:

1. Karakteristik Destinasi

Tabel 1. Karakteristik Destinasi

\begin{tabular}{|l|ll|}
\hline \multicolumn{1}{|c|}{ Parameter } & \multicolumn{1}{c|}{ Indikator } \\
\hline Lokasi & $*$ & Berkelompok atau terpisah \\
Akomodasi/ & $*$ & Jenis akomodasi : resort, \\
Trip Origin & hotel, homestay \\
& $*$ & Segmen pasar/wisatawan \\
\hline Lokasi & $*$ & Jumlah, keragaman/ tipe, \\
Atraksi/ & hirarki atraksi \\
Trip & $*$ & Terkelompok atau terisolasi \\
destination & & \\
\hline
\end{tabular}

\begin{tabular}{|l|ll|}
\hline Aksesibilitas & $*$ & Jaringan lalu lintas transportasi \\
& $*$ & Moda transportasi \\
& $*$ & Tingkat kemudahan \\
& pencapaian/ aspek kemacetan \\
& lalu lintas \\
\hline
\end{tabular}

Sumber: Basoeki, Ary (2014).

2. Karakteristik Wisatawan

Tabel 2. Karakteristik Wisatawan

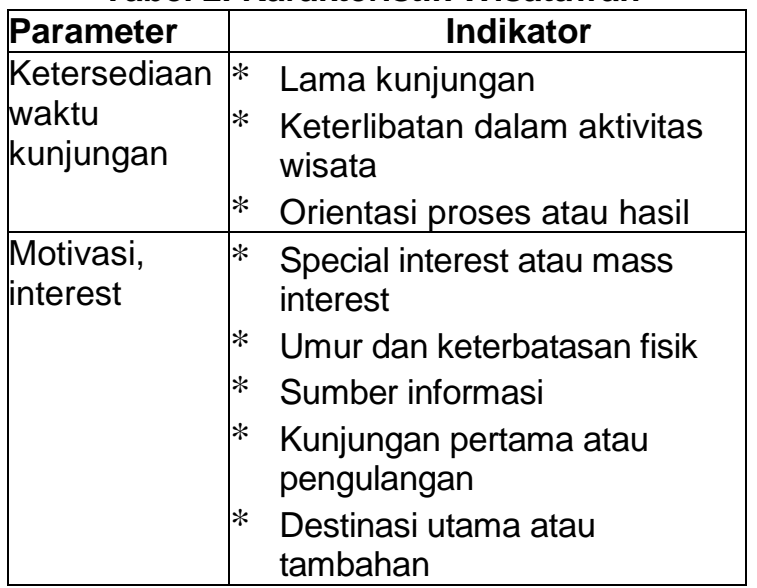

Sumber: Basoeki, Ary (2014)

\subsection{Metode Penelitian}

\subsubsection{Analisis Kebutuhan}

Metode yang digunakan dalam penulisan karya ilmiah ini ialah metode penelitian kualitatif. Sugiyono (2015:15) mengemukakan Bahwa :

"Metode penelitian kualitatif adalah metode penelitian yang berlandaskan pada filsafat postpositivisme, digunakan untuk meneliti pada kondisi obyek yang alamiah, (sebagai lawannya adalah eksperimen) dimana peneliti adalah sebagai instrumen kunci, pengambilan sampel sumber data dilakukan secara purposive dan snowball, teknik pengumpulan dengan trianggulasi (gabungan), analisis data bersifat induktif/kualitatif, dan hasil penelitian kualitatif lebih menekankan makna dari pada generalisasi".

Dengan demikian, penelitian akan berisi kutipan-kutipan data untuk memberi gambaran penyajian laporan tersebut. Data tersebut mungkin berasal dari naskah wawancara, catatan lapangan, foto, videotape, dokumen pribadi, catatan atau memo, dan dokumen resmi lainnya.

Analisis data adalah proses mencari dan menyusun secara sistematis data yang diperoleh dari hasil wawancara, catatan lapangan, dan dokumentasi dengan cara mengorganisasikan data kedalam kategori, menjabarkan ke dalam unit-unit, melakukan sintesa, menyusun kedalam pola, memilih mana yang penting dan yang akan dipelajari, dan membuat kesimpulan sehingga mudah dipahami oleh diri sendiri maupun orang lain ( 
Sugiyono, 2015:428).

Penelitian ini menampilkan data-data yang bersifat kualitatif, maka penulis menggunakan analisis data induktif. Induktif yaitu suatu analisis berdasarkan data yang diperoleh selanjutnya dikembangkan pola hubungan tertentu atau menjadi hipotesis (Bungin, 2005:70). Unit analisis yang digunakan dalam penelitian ini ialah individu yang terkait langsung dalam perkembangan Pariwisata Kabupaten Nias Barat untuk mendapatkan informasi mengenai perkembangan destinasi wisata . Pihak Kantor Dinas Pariwisata dan Kebudayaan Nias Barat selaku pihak pemerintahan yang terkait langsung dalam perkembangan dan sumber data, informasi pariwisata di Kabupaten Nias Barat. Pihak Putri Pariwisata Kabupaten Nias Barat yang merupakan pihak yang terkait dalam kegiatan mempromosikan serta memberikan informasi kegiatan dalam bentuk artikel dan dokumentasi foto. Para informan tersebut yang memberikan informasi yang nantinya akan diketahui dan dikaji oleh penulis.

\subsubsection{Variabel}

Menurut Sugiyono (2015:60) variabel penelitian pada dasarnya adalah segala sesuatu yang berbentuk apa saja yang ditetapkan oleh peneliti untuk dipelajari sehingga diperoleh informasi tentang hal tersebut, kemudian ditarik kesimpulannya.

Dalam penulisan tugas akhir ini hanya terdapat satu variabel yakni " Pola Perjalanan ", yang diuraikan sebagai berikut :

Tabel 3. Variabel, Sub-variabel dan Indikator

\begin{tabular}{|c|c|c|}
\hline Variabel & Sub-Variabel & Indikator \\
\hline \multirow[t]{3}{*}{$\begin{array}{l}\text { Pola } \\
\text { Perjalanan di } \\
\text { Kabupaten } \\
\text { Nias Barat }\end{array}$} & $\begin{array}{l}\text { Unsur - unsur } \\
\text { dalam } \\
\text { pengembangan } \\
\text { pola perjalanan } \\
\text { menuju objek } \\
\text { wisata di } \\
\text { Kabupaten Nias } \\
\text { Barat }\end{array}$ & $\begin{array}{l}\text { a. Karakateristik } \\
\text { destinasi } \\
\text { b. Karakteristik } \\
\text { wisatawan }\end{array}$ \\
\hline & $\begin{array}{l}\text { Pola Perjalanan } \\
\text { Kabupaten Nias } \\
\text { Barat }\end{array}$ & $\begin{array}{ll}\text { a. } & \text { Jenis pola } \\
& \text { perjalanan } \\
\text { b. } & \text { Entry point } \\
\text { c. } & \text { Motivasi } \\
& \text { Perjalanan } \\
\text { d. } & \text { Akomodasi } \\
\text { e. } & \text { Cara } \\
& \text { melakukan } \\
\text { f. Jenis objek } \\
\text { wisata } \\
\text { g. } \text { Waktu dan } \\
\text { jarak tempuh }\end{array}$ \\
\hline & $\begin{array}{l}\text { Fungsi pola } \\
\text { perjalanan }\end{array}$ & $\begin{array}{l}\text { Sumber informasi } \\
\text { untuk wisatawan }\end{array}$ \\
\hline
\end{tabular}

Sumber : Data diolah oleh penulis ( 2019)

\subsubsection{Prosedur Pengumpulan Data}

Adapun prosedur pengumpulan data yang digunakan dalam penelitian ini ialah data primer diperoleh melalui sumber data dari Dinas Pariwisata dan Kebudayaan Kabupaten Nias Barat serta pihak terkait pengelolaa objek wisata melalui wawancara, dokumentasi, dan observasi.

\subsection{Hasil dan Pembahasan}

Berdasarkan hasil kajian (observasi, wawancara, dokumentasi dan studi kepustakaan) terkait dengan destinasi wisata di daerah kabupaten Nias Barat maka dapat diuraikan seperti berikut ini.

\subsubsection{Destinasi wisata di Kecamatan Sirombu}

Dari hasil pengumpulan data yang telah dilakukan oleh peneliti di Kabupaten Nias Barat dengan melakukan observasi, wawancara, dokumentasi dan studi kepustakaan kepada perwakilan instansi pemerintah serta pihak yang berkepentingan terkait dengan destinasi yang ada di Kecamatan Sirombu yang termasuk dalam destinasi wisata bahari, wisata sejarah/budaya dan wisata alam tersusun dan terinventarisasi dalam tabel dan daftar sebagai berikut :

Tabel 4. Data destinasi wisata di Kecamatan Sirombu

\begin{tabular}{|c|l|l|}
\hline No. & \multicolumn{1}{|c|}{ Objek Wisata } & \multicolumn{1}{|c|}{ Jenis Wisata } \\
\hline 1. & Pantai Sirombu & Wisata Bahari \\
\hline 2. & Pantai Gu'u & Wisata Bahari \\
\hline 3. & Pantai Fadaya & Wisata Bahari \\
\hline 4. & Pantai Ture & Wisata Bahari \\
\hline 5. & Pantai Asu & Wisata Bahari \\
\hline 6. & Pantai Valaete & Wisata Bahari \\
\hline 7. & Pantai Fari'i & Wisata Bahari \\
\hline 8. & Pulau Bawa & Wisata Bahari \\
\hline
\end{tabular}

Sumber : Data diolah oleh Penulis, 2019

4.1.2. Destinasi wisata di Kecamatan Lahomi

Dari hasil pengumpulan data yang telah dilakukan oleh peneliti di Kabupaten Nias Barat dengan melakukan observasi, wawancara, dokumentasi dan studi kepustakaan kepada perwakilan instansi pemerintah serta pihak yang berkepentingan terkait dengan destinasi yang ada di Kecamatan Lahomi yang termasuk dalam destinasi wisata bahari, wisata sejarah/budaya dan wisata alam tersusun dan terinventarisasi dalam tabel dan daftar sebagai berikut :

Tabel 5. Data destinasi wisata di Kecamatan Lahomi

\begin{tabular}{|l|c|c|}
\hline No. & Objek Wisata & Jenis Wisata \\
\hline
\end{tabular}




\begin{tabular}{|c|l|l|}
\hline 1. & $\begin{array}{l}\text { Batu Megalith Desa } \\
\text { Onolimbu }\end{array}$ & $\begin{array}{l}\text { Wisata Sejarah } \\
\text { dan } \\
\text { Budaya }\end{array}$ \\
\hline 2. & $\begin{array}{l}\text { Rumah Adat Nias } \\
\text { Barat }\end{array}$ & $\begin{array}{l}\text { Wisata } \\
\text { Sejarah dan } \\
\text { Budaya }\end{array}$ \\
\hline 3. & Bukit Hermon & Wisata Alam \\
\hline
\end{tabular}

Sumber : Data diolah oleh penulis, 2019

\subsubsection{Destinasi wisata di Kecamatan} Mandrehe

Dari hasil pengumpulan data yang telah dilakukan oleh peneliti di Kabupaten Nias Barat dengan melakukan observasi, wawancara, dokumentasi dan studi kepustakaan kepada perwakilan instansi pemerintah serta pihak yang berkepentingan terkait dengan destinasi yang ada di Kecamatan Mandrehe yang termasuk dalam destinasi wisata bahari, wisata sejarah/budaya dan wisata alam tersusun dan terinventarisasi dalam tabel dan daftar sebagai berikut:

Tabel 6. Data destinasi wisata di Kecamatan Mandrehe

\begin{tabular}{|r|l|l|}
\hline No. & \multicolumn{1}{|c|}{ Objek Wisata } & \multicolumn{1}{|c|}{ Jenis Wisata } \\
\hline 1. & Batu Megalith & $\begin{array}{l}\text { Wisata Sejarah } \\
\text { dan } \\
\text { Budaya }\end{array}$ \\
\hline 2. & $\begin{array}{l}\text { Batu Megalith } \\
\text { Hiligoe }\end{array}$ & $\begin{array}{l}\text { Wisata } \\
\text { Sejarah dan } \\
\text { Budaya }\end{array}$ \\
\hline
\end{tabular}

Sumber : Data diolah oleh penulis, 2019

4.1.4. Destinasi wisata di Kecamatan Mandrehe Utara

Dari hasil pengumpulan data yang telah dilakukan oleh peneliti di Kabupaten Nias Barat dengan melakukan observasi, wawancara, dokumentasi dan studi kepustakaan kepada perwakilan instansi pemerintah serta pihak yang berkempentingan terkait dengan destinasi yang ada di Kecamatan Mandrehe Utara yang termasuk dalam destinasi wisata bahari, wisata sejarah/budaya dan wisata alam tersusun dan terinventarisasi dalam tabel dan daftar sebagai berikut :

Tabel 7. Data destinasi wisata di Kecamatan Mandrehe Utara

\begin{tabular}{|c|c|c|}
\hline No. & Objek Wisata & Jenis Wisata \\
\hline 1. & Bale & Alam \\
\hline
\end{tabular}

Sumber : Data diolah oleh penulis, 2019

\subsubsection{Komponen 3A (Accessibility,} Attraction, Amenities) di kabupaten Nias Barat

Dari hasil pengumpulan data yang telah dilakukan oleh peneliti di Kabupaten Nias Barat dengan melakukan bservasi, wawancara, dokumentasi dan studi kepustakaan kepada perwakilan instansi pemerintah serta pihak yang berkempentingan terkait dengan data komponen produk wisata di Kabupaten Nias Barat tersusun dan terinventarisasi dalam tabel dan daftar sebagai berikut :

Tabel 8. Komponen 3A di Kabupaten Nias Barat

\begin{tabular}{|c|c|c|}
\hline Komponen & Elemen & Ket. \\
\hline \multirow{4}{*}{ Accessibility } & $\begin{array}{l}\text { Infrastruktur / Moda } \\
\text { Transportasi }\end{array}$ & Ada \\
\hline & Jalan & Ada \\
\hline & Bandara & Ada \\
\hline & Pelabuhan Laut & Ada \\
\hline \multirow{3}{*}{ Atrraction } & Wisata Alam & Ada \\
\hline & Wisata Bahari & Ada \\
\hline & $\begin{array}{c}\text { Wisata Sejarah dan } \\
\text { Budaya }\end{array}$ & Ada \\
\hline \multirow{9}{*}{ Amenities } & Akomodasi & Ada \\
\hline & $\begin{array}{c}\text { Restoran lokal } \\
\text { ( muslim/non muslim } \\
\text { ) }\end{array}$ & Ada \\
\hline & Transportasi & Ada \\
\hline & Salon Kecantikan & Ada \\
\hline & Retail Outlet & Ada \\
\hline & Bank / ATM & Ada \\
\hline & Apotik & Ada \\
\hline & Puskesmas & Ada \\
\hline & Hiburan & $\begin{array}{l}\text { Tidak } \\
\text { Ada }\end{array}$ \\
\hline
\end{tabular}

Sumber : Data diolah oleh penulis, 2019

Gambaran data pada tabel diatas menyatakan bahwa komponen 3A di Kabupaten Nias Barat adalah :

1. Aksesibilitas menuju destinasi wisata di Kabupaten Nias Barat cukup baik dengan kondisi jalan yang baik. Kabupaten Nias Barat memiliki 2 buah entry point yaitu Bandar Udara Binaka dan Pelabuhan Gunungsitoli. Untuk mencapai beberapa destinasi antar pulau memiliki entry point yaitu Dermaga Sirombu. Untuk mencapai destinasi wisata dapat menggunakan kendaraan pribadi atau sewa mobil apabila melalui jalur darat, atau bisa menggunakan perahu atau kapal motor penumpang menuju pelabuhan terdekat dari objek wisata yang menjadi tujuan.

2. Atraksi wisata di Kabupaten Nias Barat di kategorikan kedalam atraksi wisata alam, wisata bahari, atraksi wisata kebudayaan dan sejarah, dan daya tarik khusus. Beberapa aktivitas wisata yang bisa dilakukan di destinasi wisata Kabupaten Nias Barat antara lain: sightseeing, surfing, snorkeling, memancing, mengunjungi berbagai peninggalan sejarah.

3. Sarana penunjang pariwisata di Kabupaten 
Nias Barat antara lain restaurant lokal, toko souvenir, pasar, bank, puskesmas, apotik, kantor polisi, kantor pos dan Akomodasi. Untuk mendukung aktivitas pariwisata di Kabupaten Nias Barat, saat ini telah ada 14 penginapan/hotel non berbintang di Kabupaten Nias Barat yang terdaftar di Dinas Penanaman Modal dan Pelayanan Perizinan Terpadu Satu Pintu Kabupaten Nias Barat yang semuanya berada di kawasan kecamatan Sirombu.

\subsubsection{Kajian tentang Rute perjalanan} wisata di Kabupaten Nias Barat

Dari hasil kegiatan peneliti dalam pengumpulan data melalui observasi, wawancara, dokumentasi, dan studi kepustakaan untuk rute perjalanan wisata beberapa destinasi wisata alam, wisata bahari, wisata sejarah/budaya terhimpun dalam tabel berikut :

Tabel 9. Rute perjalanan wisata di Kabupaten Nias Barat

\begin{tabular}{|c|c|c|c|}
\hline Departure & Arrive & $\begin{array}{l}\text { Waktu } \\
\text { Tempuh }\end{array}$ & Jarak \\
\hline $\begin{array}{l}\text { Bandara } \\
\text { Binaka ( Via } \\
\text { Udara ) / } \\
\text { Pelabuhan } \\
\text { Gunungsitoli } \\
\text { ( Via Laut ) }\end{array}$ & $\begin{array}{l}\text { Batu } \\
\text { Megalith } \\
\text { Hiligoe }\end{array}$ & 90 Menit & $\begin{array}{l}50 \\
\mathrm{Km}\end{array}$ \\
\hline $\begin{array}{l}\text { Batu Megalith } \\
\text { Hiligoe }\end{array}$ & Bale & 20 Menit & $8 \mathrm{Km}$ \\
\hline Bale & $\begin{array}{l}\text { Pantai } \\
\text { Sirombu }\end{array}$ & 60 Menit & \begin{tabular}{|c|}
35 \\
$\mathrm{Km}$
\end{tabular} \\
\hline $\begin{array}{l}\text { Desa } \\
\text { Sirombu }\end{array}$ & Pantai Fari'i & 35 Menit & $\begin{array}{c}16 \\
\mathrm{Km}\end{array}$ \\
\hline Pantai Fari'i & $\begin{array}{l}\text { Pantai } \\
\text { Valaete }\end{array}$ & 15 Menit & $5 \mathrm{Km}$ \\
\hline Pantai Valaete & $\begin{array}{l}\text { Batu } \\
\text { Megalith } \\
\text { Desa } \\
\text { Onolimbu }\end{array}$ & 40 Menit & $\begin{array}{c}17 \\
\mathrm{Km}\end{array}$ \\
\hline $\begin{array}{l}\text { Megalith Desa } \\
\text { Onolimbu }\end{array}$ & Rumah Adat & 5 Menit & $\begin{array}{l}0.03 \\
\mathrm{Km}\end{array}$ \\
\hline Rumah Adat & \begin{tabular}{|l} 
Bukit \\
Hermon
\end{tabular} & 45 Menit & $\begin{array}{l}25 \\
\mathrm{Km}\end{array}$ \\
\hline \begin{tabular}{|l} 
Dermaga \\
Sirombu
\end{tabular} & Pulau Bawa & 60 Menit & - \\
\hline Pulau Bawa & \begin{tabular}{|l|} 
Pantai \\
Fadaya
\end{tabular} & 60 Menit & - \\
\hline $\begin{array}{l}\text { Pantai } \\
\text { Fadaya } \\
\end{array}$ & Pantai Ture & 20 Menit & $5 \mathrm{Km}$ \\
\hline Pantai Ture & Pantai Gu'u & 20 Menit & $5 \mathrm{Km}$ \\
\hline \begin{tabular}{|l} 
Dermaga \\
Sirombu
\end{tabular} & Pulau Asu & 90 Menit & - \\
\hline Sirombu & Batu & 45 Menit & $\begin{array}{l}25 \\
\mathrm{Km}\end{array}$ \\
\hline
\end{tabular}

Sumber : Data diolah oleh penulis, 2019

Gambaran data pada tabel diatas menyatakan bahwa rute perjalanan wisata yang diarahkan oleh peneliti untuk wisatawan di Kabupaten Nias Barat menyatakan bahwa :

1. Di hari pertama objek wisata yang akan dikunjungi oleh wisatawan adalah Batu Megalith Hiligoe, Bale dan Pantai Sirombu. Wisatawan akan memulai perjalanan dari 2 entry point yang dipilih yaitu Bandara Binaka ( Via udara ) / Pelabuhan Gunungsitoli ( Via Laut ). Jarak Tempuh dari entry point ke objek wisata yang akan dikunjungi pertama kali adalah $50 \mathrm{Km}$. Dari Batu Megalith Hiligoe wisatawan akan menuju Bale yang waktu tempuh perjalanan 20 menit. Dari Bale wisatawan akan menuju Pantai Sirombu dan mengakhiri perjalanan di hari pertama di Kecamatan Sirombu. Aktivitas yang dilakukan di hari pertama antara lain : sightseeing, menikmati peninggalan sejarah dan budaya, berenang, menikmati sunset dan ativitas lainnya.

2 Di hari kedua objek wisata yang akan dikunjungi adalah Pantai Fari'i, Pantai Valaete, Batu Megalith Desa Onolimbu, Rumah Adat dan Bukit Hermon. Starting point perjalanan adalah dari penginapan di Kecamatan Sirombu menuju Pantai Fari'i dengan waktu tempuh 35 menit dan jarak tempuh $16 \mathrm{Km}$. Dari Pantai Fari'i wisatawan akan menuju Pantai Valaete dengan waktu tempuh perjalanan adalah 15 menit. Objek wisata yang dikunjungi selanjutnya adalah Batu Megalith Desa Onolimbu dan Rumah Adat. Aktivitas yang dilakukan di hari kedua antara lain : sightseeing, menikmati peninggalan sejarah dan budaya, berenang dan ativitas lainnya.

3. Di hari ketiga objek wisata yang dikunjungi adalah Pulau Bawa, Pantai Fadaya, Pantai Ture dan Pantai Gu'u. Perjalanan akan dimulai dari dermaga sirombu menuju Pulau Bawa dengan waktu tempuh 60 menit. Rute perjalanan selanjutnya dari Pulau Bawa menuju Pantai Fadaya yang terletak di kecamatan Sirombu dengan waktu tempuh 60 menit. Wisatawan akan mengakhiri perjalanan di hari ketiga dengan mengunjungi Pantai Gu'u yang bisa di tempuh dengan berjalan kaki sekitar 10 menit. Aktivitas yang dilakukan di hari ketiga antara lain : sightseeing, snorkeling, memancing, berenang, menikmati sunset dan ativitas lainnya.

4. Di hari Keempat objek wisata yang akan dikunjungi adalah Pulau Asu. Waktu tempuh dari Dermaga Sirombu menuju Pulau Asu adalah 90 menit dan akan melakukan aktivitas sepanjang hari di 
Pulau Asu. Aktivitas yang dilakukan di hari keempat antara lain : sightseeing, snorkeling, memancing, berenang, menikmati sunset dan aktivitas lainnya.

5. Di hari Kelima wisatawan akan memulai perjalanan dari Pulau Asu menuju Dermaga sirombu dengan waktu tempuh 60 menit. Selanjutnya wisatawan akan bergerak menuju objek wisata Batu Megalith Tokhombowo dengan waktu tempuh sekitar 45 menit dan jarak tempuh sekitar $25 \mathrm{Km}$. Dari Batu Megalith Tokhombowo wisawatan akan melakukan perjalanan kembali ke entry point yaitu Bandara Binaka (Via udara) / Pelabuhan Gunungsitoli (Via Laut). Rute Perjalanan wisatawan akan berakhir disini. Aktivitas yang dilakukan di hari kelima antara lain : menikmati peninggalan sejarah dan budaya serta aktivitas lainnya.

4.1.7. Kajian Tentang Pengembangan Pola Perjalanan (travel pattern) di Kabupaten Nias Barat

Mengetahui bagaimana pola perjalanan wisata di Kabupaten Nias Barat, peneliti telah melakukan identifikasi terhadap data dan informasi yang diperoleh melalui observasi, wawancara, dokumentasi, dan studi kepustakaan untuk pola perjalanan wisata destinasi wisata alam, wisata bahari, wisata sejarah/budaya di Kabupaten Nias Barat. Untuk mempermudah dalam menginterpretasikan hasil penelitian, peneliti mengacu pada pengembangan Pola Perjalanan berdasarkan karakteristik destinasi dan karakteristik wisatawan. Berikut tabel pengembangan pola perjalanan di Kabupaten Nias Barat.

Tabel 10. Variabel dan Parameter Pengembangan pola perjalanan di Kabupaten Nias Barat

\begin{tabular}{|c|c|c|}
\hline Parameter & Indikator & Keterangan \\
\hline \multicolumn{3}{|c|}{ Variabel Karakteristik Destinasi } \\
\hline \multirow{3}{*}{$\begin{array}{l}\text { Lokasi } \\
\text { Akomodasi }\end{array}$} & $\begin{array}{l}\text { Berkelompok } \\
\text { atau terpisah }\end{array}$ & $\begin{array}{l}\text { Tersedia untuk } \\
\text { berkelompok dan } \\
\text { terpisah }\end{array}$ \\
\hline & \begin{tabular}{|l} 
Jenis \\
Akomodasi
\end{tabular} & $\begin{array}{l}\text { Homestay dan } \\
\text { Penginapan }\end{array}$ \\
\hline & $\begin{array}{l}\text { Segmentasi } \\
\text { Pasar }\end{array}$ & $\begin{array}{l}\text { Wisatawan } \\
\text { domestik dan } \\
\text { mancanegara }\end{array}$ \\
\hline $\begin{array}{l}\text { Lokasi } \\
\text { Atraksi }\end{array}$ & $\begin{array}{l}\text { Jumlah, } \\
\text { Keragaman / } \\
\text { tipe, hirarki } \\
\text { atraksi }\end{array}$ & $\begin{array}{l}\text { Terdapat } 14 \text { objek } \\
\text { wisata yang } \\
\text { dikategorikan } \\
\text { kedalam wisata } \\
\text { alam, wisata } \\
\text { bahari, wisata } \\
\text { sejarah/budaya }\end{array}$ \\
\hline
\end{tabular}

\begin{tabular}{|c|c|c|}
\hline Parameter & Indikator & Keterangan \\
\hline \multirow{4}{*}{ Aksesibilitas } & $\begin{array}{l}\text { Infrastruktur / } \\
\text { Moda } \\
\text { transportasi }\end{array}$ & $\begin{array}{l}\text { Bus penumpang, } \\
\text { mobil pribadi, } \\
\text { kapal penumpang } \\
\text { tradisional dan } \\
\text { speedboad } \\
\end{array}$ \\
\hline & $\begin{array}{l}\text { Jalan } \\
\text { (jaringan lalu } \\
\text { lintas } \\
\text { transportasi ) }\end{array}$ & Sistem 2 arah \\
\hline & Bandara & $\begin{array}{l}\text { Bandara udara } \\
\text { domestik (binaka } \\
\text { - GNS ) }\end{array}$ \\
\hline & $\begin{array}{l}\text { Pelabuhan } \\
\text { laut }\end{array}$ & \begin{tabular}{|l} 
Pelabuhan laut \\
Gunungsitoli dan \\
Dermaga Sirombu
\end{tabular} \\
\hline \multicolumn{3}{|c|}{ Karakteristik Wisatawan } \\
\hline \multirow{2}{*}{\begin{tabular}{|l|} 
Ketersediaan \\
waktu \\
kunjungan
\end{tabular}} & $\begin{array}{l}\text { Lama } \\
\text { kunjungan }\end{array}$ & 5 hari 4 malam \\
\hline & $\begin{array}{l}\text { Keterlibatan } \\
\text { dalam } \\
\text { aktivitas } \\
\text { wisata } \\
\end{array}$ & Bersifat aktif \\
\hline \multirow{3}{*}{$\begin{array}{l}\text { Motivasi dan } \\
\text { Interest } \\
\text { Wisatawan }\end{array}$} & $\begin{array}{l}\text { Motivasi } \\
\text { wisatawan }\end{array}$ & $\begin{array}{l}\text { leisure/pleasure } \\
\text { travel }\end{array}$ \\
\hline & Special & adventure \\
\hline & $\begin{array}{l}\text { Kelompok } \\
\text { usia }\end{array}$ & Remaja, dewasa \\
\hline
\end{tabular}

Gambaran data pada tabel diatas menyatakan bahwa pola perjalanan wisata yang diarahkan oleh peneliti untuk wisatawan di Kabupaten Nias Barat adalah:

1. Jenis pola perjalanan yang diarahkan oleh peneliti adalah Destination Region Loop yaitu kombinasi antara single point dan chaining loop yang dikenal dengan nama Regional Tour Destination Area Loop. Pola perjalanan ini menunjukkan bahwa wisatawan akan melakukan perjalanan di Kabupaten Nias Barat dengan mengunjungi beberapa destinasi atau daya tarik wisata tanpa mengulangi dan kembali ke entry point (Bandara Binaka Gunungsitoli dan Pelabuhan laut Gunungsitoli) dengan rute yang sama.

2. Pola perjalanan ini dipengaruhi oleh motivasi perjalanan dari wisatawan yaitu motivasi untuk bersenang senang ( leisure/pleasure travel ) dengan ketertarikan khusus pada adventure, agricultural/agro, marine, special interest, health, historical, educational, family visit, religious, sport dan lain sebagainya.

3. Selama melakukan perjalanan di 
Kabupaten Nias Barat, wisatawan akan menginap selama 3 malam di penginapan yang terletak di Desa Sirombu dan 1 malam di penginapan yang terletak di Pulau Asu.

4. Berdasarkan cara melakukan, pola perjalanan yang diarahkan oleh peneliti bisa dilakukan oleh GIT (Grouped Inclusive Travel) dengan jumlah maksimal peserta sebanyak 20 pax dan FIT (Free Individual Travel).

5. Moda Transportasi pada pola perjalanan

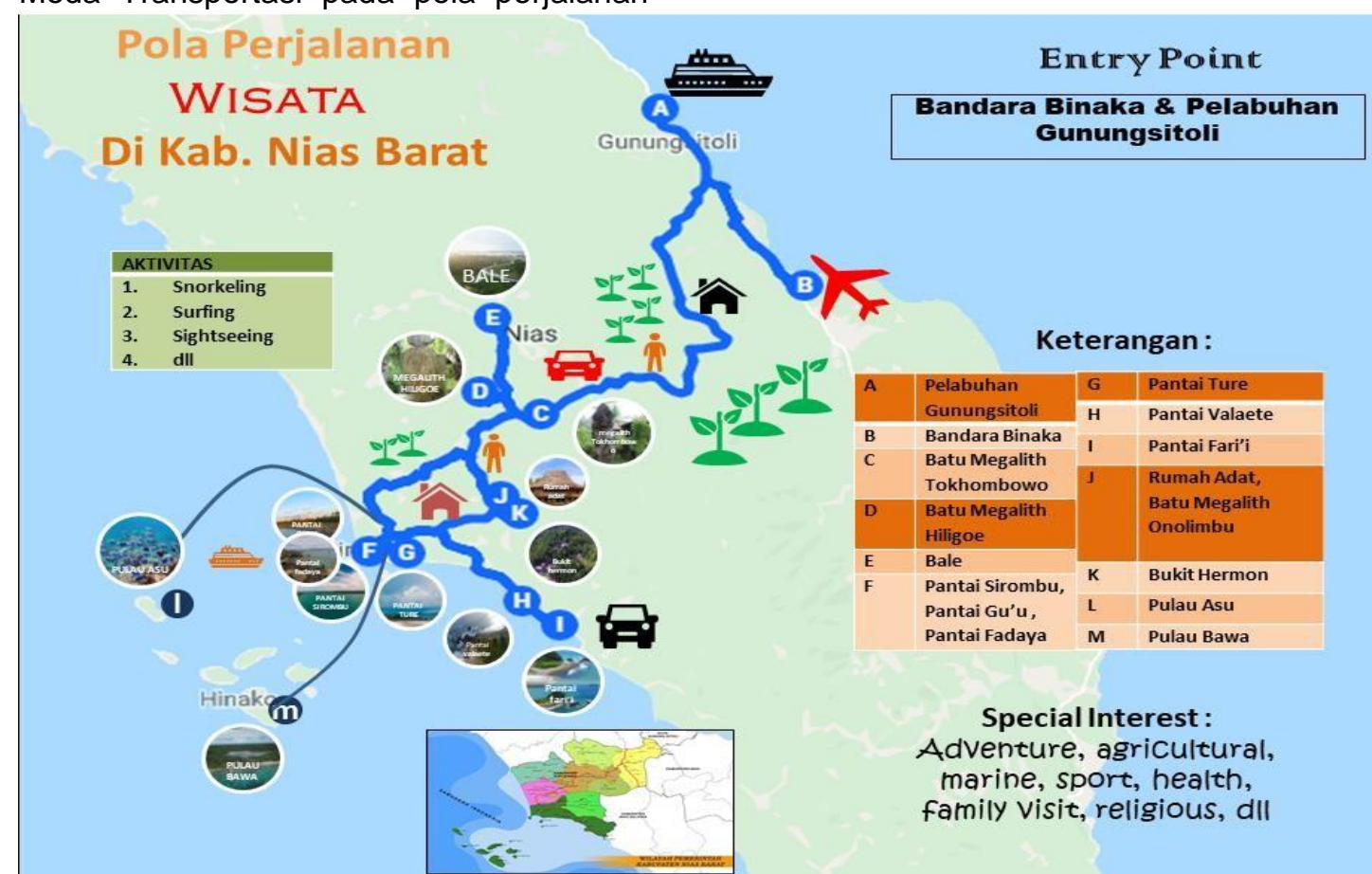

Sumber: Data Olahan Penulis (2019)

Gambar 1. Tampilan Pola Perjalanan Wisata Di Kabupaten Nias Barat Setelah Pengembangan

\subsection{Kesimpulan dan Saran}

Berdasarkan hasil penelitian yang dilakukan dapat disimpulkan bahwa:

1. Nias Barat merupakan memiliki potensi wisata yang seharusnya dapat dikembangkan untuk menarik lebih banyak kunjungan. Terbukti terdapat sekitar 14 objek wisata alam dan sejarah yang dapat ditawarkan pada wisatawan di kabupaten ini.

2. Untuk membentuk sebuah rute perjalanan yang efisien, sebaiknya ada kombinasi jenis tujuan wisata yang dikunjungi, misalnya dengan mengunjungi objek wisata sejarah, seperti Batu Megalith Hiligoe lalu dilanjutkan dengan kunjungan dengan Pantai Sirombu sambil menyusuri pantai-pantai lain disekitarnya.

3. Rute perjalanan wisata (travel pattern yang cocok untuk digunakan di Nias selatan adalah dengan menggunakan pendekatan destination region loop,dengan ini akan disesuaikan dengan jumlah wisatawan saat melakukan perjalanan. Wisatawan akan menggunakan bus, mini van, mobil sedan, kapal tradisional dan speedboat.

6. Pola perjalanan ini mengarahkan wisatawan untuk melakukan perjalanan berdasarkan rute perjalanan yang telah disusun oleh peneliti di tabel 9 (rute perjalanan wisata di Kabupaten Nias Barat). 
jauh, sehingga transit point dapat menjadi penolong refreshment.

\section{Daftar Pustaka}

[1] Dinas Pariwisata dan Kebudayaan Kabupaten Nias Barat. (2018). Buku Pesona Tano Aekhula. Kabupaten Nias Barat : Dinas Pariwisata dan Kebudayaan Kabupaten Nias Barat.

[2] Badan Pusat Statistik (BPS) Kabupaten Nias Barat. (2017). Nias Barat Dalam Angka Tahun 2017. Kabupaten Nias Barat : Badan Pusat Statistik (BPS) Kabupaten Nias Barat.

[3] Pendit, Nyoman S. (1994). Ilmu Pariwisata: Sebuah Pengantar Perdana. Jakarta: Pradnya Paramita.

[4] Hadiwojoyo, Surya Sakti. (2012). Perencanaan Pariwisata Pedesaan Berbasis Masyarakat (sebuah pendekatan konsep). Yogyakarta : Graha Ilmu

[5] Sihite, Richard. (2000). Tourims Industry (Kepariwisataan). Surabaya : SIC Middleton, Victor T.C. (2001). Marketing In Travel and Tourism ( $3^{\text {rd }}$ ed). Bodmin : MPG Books Ltd.

[6] Sugiyono. (2015). Metode Penelitian Pendidikan. Bandung: Alfabeta.
[7] Bungin, Burhan. (2005). Analisis data penelitian Kualitatif ( edisi 1 ). Jakarta : PT.Raja Grafindo Persada.

[8] Ismedi, Edwin. (Mei 2011). Penyusunan Pola Perjalanan Wisata DIY. Materi disajikan dalam Seminar ASITA, di Yogyakarta.

[9] Tim Penyusun Pusat Kamus. (2007). Kamus Besar Bahasa Indonesia (KBBI). Jakarta : Balai Pustaka

[10] Undang - Undang Republik Indonesia Nomor 10 ,Tahun 2009 tentang Kepariwisataan.

[11]Fajri, Khoirul, Indrianty, Septy \& Edison, Emron. (2018). Pola Perjalanan Paket Wisata Budaya, Sejarah, dan religi sebagai produl wisata unggulan di Priangan Timur, CIAMAJAKUNING, Jawa Barat. Bandung : Sekolah Tinggi Ilmu Ekonomi Pariwisata Yapari. Diunduh pada tanggal 28 september dari https://journal.stpsahid.ac.id/index.php/stp/ article/view/129

[12] Susanto, Dedi.(2018). Pola Perjalanan Wisata Bahari Kabupaten Bintan Barat. Riau : Universitas Riau. Diunduh pada tanggal 28 september 2018 dari https://jom.unri.ac.id/index.php/JOMFSIP/a rticle/viewFile/18246/17624 